\title{
The usefulness of soil-agricultural maps to identify classes of soil truncation
}

\begin{abstract}
Soil erosion led to the severe transformations of the soil cover of young morainic areas of northern Poland. Main alterations are connected with soil truncation on summits and in upper part of slopes, whereas at foot slopes and within depressions colluvial material is accumulated. Information and knowledge about the extent or intensity of erosion are mainly derived from sophisticated geospatial models or laborious field works. To reduce the effort associated with development of studies on erosion the use of easily available cartographic sources is required. The main aim of the paper is an elaboration of key to reinterpret information taken from soil-agricultural maps in the context of determining the degree of pedons truncation. The study is based on a comparison of the properties of soils representing various classes of erosional alterations with the data on existing maps. The correlation between descriptions recorded in the form of cartographic symbols with properties of pedons divided into several classes of vertical texturecontrast soil truncation and results from potential erosion maps was elaborated. The application of developed interpretative principles allows calculating the share of soil truncation classes within investigated area. The five test plots $\left(\mathrm{each}-1 \mathrm{~km}^{2}\right)$ were located along the north slopes of Noteć Middle Valley and Torun Basin. The proposed interpretation of soil-agricultural maps reveals their significant value in studies on extent and degree of erosional alterations recorded in soil cover.
\end{abstract}

Key words: soil cover, soil erosion, clay-illuvial soils, morainic landscapes, north Poland

\section{INTRODUCTION}

Soil erosion is a common phenomenon leading to the widespread transformation of the soil cover of Poland (Rejman and Rodzik 2006). Józefaciuk and Józefaciuk (1992) estimated that ca. $30 \%$ of the total area of the country is altered by this process. Maximum annual soil losses induced by water surface erosion in Poland can reach up to $280 \mathrm{Mg} \cdot \mathrm{km}^{-2}$ (Maruszczak 1991). The area undergoing significant erosional transformations covers about $7.0 \%$ of the country's area (Wawer and Nowocień 2007). Recent assessment of actual erosion risk done based on the USLE approach (Drzewiecki et al. 2014) showed that more than 25\% of Małopolska Voivodeship area is threatened by moderate, average, strong or very strong erosion.

The most susceptible to soil erosion are mountain regions of southern Poland (Latocha 2012, Święchowicz 2012) and uplands (Wawer and Nowocień 2007, Paluszek 2010, 2013). Significant intensity of denudation processes was also recorded in young morainic landscapes of northern Poland (Uggla et al. 1968, Sinkiewicz 1998, Orzechowski 2008).

In particular, agricultural use of soil led to the intensification and development of the slope processes (e.g. Marcinek and Komisarek 2004, Świtoniak 2014). As a result, soil truncation occurred on summits and in upper part of slopes, whereas at foot slopes and within depressions colluvial material was accumulated (Bieniek 1997, Klimowicz and Uziak 2001, Przewoźna 2014, Świtoniak 2015, Świtoniak et al. 2016).

Information and knowledge about the extent or intensity of erosional alterations of soil cover in Poland are mainly derived from geospatial models (e.g. Wawer and Nowocień 2007, Drzewiecki and Mularz 2005, Drzewiecki et al. 2014) or field works (e.g. Marcinek and Komisarek 2004, Świtoniak 2014). In the first case it is necessary to use of advanced GIS techniques and detailed environmental data. The calculations of these models can cause many difficulties even after attempts to simplification (Kaszubkiewicz et al. 2011). Assessment and mapping of soil erosion on the basis of field works consuming a lot of time and is labor intensive (Olson et al. 1994, Szrejder 1998, Świtoniak and Bednarek 2014).

To reduce the effort associated with development of studies on erosion the use of easily available cartographic sources is required. Considering abundant content and coverage of all the agricultural part of the country, soil-agricultural maps in scale 1:25000 appear to be very useful in erosional researches. In previous studies these maps were used for various purposes e.g. rural planning and agricultural production, environmental protection, mapping of agricultural soil 
quality in general (Dobers et al. 2010) or dividing agricultural lands into particular fields (Strzemski 1985). To assess the erosional processes they have been used in the aforementioned models of actual and potential water erosion of Poland (Wawer and Nowocień 2007) or Małopolska voivodship (Drzewiecki et al. 2014).

The soil-agricultural maps contain eighteen different soil types and 23 different soil-texture classes (Dobers et al. 2010). Therefore, information about soil properties and pedogenesis is very detailed. Nevertheless, that data come from the 1950s and 1960s and they are outdated in terms of soil systematics. Moreover, at a time when these maps were created role of erosion processes was underestimated. It is evidenced by the total absence of the types of eroded pedons (arenosols, regosols) and the rare occurrence of colluvial soil (Świtoniak 2015).

The main aim of the paper is an elaboration of key to reinterpret information taken from soil-agricultural maps in the context of determining the degree of pedons truncation. The study is based on a comparison of the properties of soils representing various classes of erosional alterations with the data on existing maps. The obtained data will also be tested for mapping of extent and degree of erosional alterations of soil cover within selected young morainic areas of Poland.

\section{STUDY AREA AND METHODS}

The investigated area is located along the north slopes of Noteć Middle Valley and Torun Basin (Fig. 1) which constitute a part of the Torun-Eberswalde ice-marginal stream valley. It was formed during the Pomeranian Phase of the last glaciation (Galon 1958, Weckwerth 2010). The bottom part of the valley lies at an altitude about 58-60 $\mathrm{m}$ a.s.l. The slopes are built of glacial tills and sands and rise to a height about 98-100 m a.s.l. to the surface of Krajna morainic plateau. Significant inclination and irregular relief are characteristic features of the slopes. They are dissected by numerous small denudation-erosion valleys and nivation niches (Ratajczak-Szczerba and Paluszkiewicz 2015). Whole investigated area was used for agricultural purposes and therefore was also exposed to strong erosion processes in the past. Severe influence of human-induced erosion on soil cover in this region was already described by Pietrzak (2014). In order to conduct detailed studies five test plots have been selected: 1 - Anieliny, 2 - Trzeciewnica, 3 -Dębowa Góra, 4 - Ślesin, 5 - Las Minikowski (Fig. 1). The surface of each quadratic in shape test plot is $1 \mathrm{~km}^{2}$.

To assess the extent and degree of the erosional alteration of soil cover, potential erosion maps on a scale of 1:10 000 have been drawn. The actual intensity



FIGURE 1. Location of test plots: 1 - Anieliny, 2 - Trzeciewnica, 3 - Dębowa Góra, 4 - Ślesin, 5 - Las Minikowski 
of slope processes was not taken into consideration because nowadays almost the entire area of investigated slopes is covered by forests or grass vegetation, which protects soils against erosion. Model of potential erosion was created using Wawer and Nowocień (2007) procedure. Classes grades of erosion intensity (0-5) were distinguished by an overlay of layers representing: soil texture, slope and land use type. The particular layers were made based on available cartographic materials - topographic map in scale 1:10 000 (slope), soil-agricultural maps in scale 1:25 000 (Sadki and Nakło sheets - texture) and orthophotomap (geoportal.gov.pl; land use type). As a climatic factor average annual rainfall below $600 \mathrm{~mm}$ was taken.

To create Digital Terrain Model and slope map (DTM), contour lines were digitized in ArcGIS, with $1.25 \mathrm{~m}$ interval. Resolution $(5 \mathrm{~m})$ of slope and potential erosion map was determined, based on the formula of Abarca (2006) modified by Sobiech (2012).

Soil-agricultural maps in scale 1:25 000 (Sadki and Nakło sheets - Fig. 2) were also used to create maps of soil cover. After scanning, calibration and rectification processes contours of soil units have been digitized. Soil types (Polish Soil Classification - PSC 2011) have been determined on the basis of reinter- pretation of soil-agricultural maps designations (Bednarek et al. 2005). The English names of soil units according to PSC (2011) were given after Świtoniak et al. (2016) and correlated with WRB (IUSS Working Group WRB, 2015).

\section{RESULTS}

Existing soil-agricultural maps show within investigated slopes the dominance of clay-illuvial soils (PSC 2011) developed from glacial loamy material. According to WRB they can be classified mainly as Luvisols, and in some cases as Planosols or Alisols. This group includes the contours marked by letters A or B $(\mathrm{Bw})$ with significant vertical texture-contrast, e.g. pgl:gś; pgm:gś; gl(p):gś (Świtoniak 2014, Fig. 2).

The second group represents soils developed from vertically homogenous loamy material and designated by letter B (e.g. B gl or B gś). These soils have been often described as brown earths (WRB - Cambisols) in the past (Cieśla 1968, Cieśla et al. 1978). Nevertheless, recent studies indicate that these pedons should be also classified as the partially eroded clay-illuvial soils. The disappearance of eluvial zone and lack of vertical texture-contrast in these soils is a consequence of soil truncation (Kobierski 2013, Podlasiński 2013,


FIGURE 2. Soil-agricultural maps of test plots 
Świtoniak et al. 2016). Apart from the loamy material, in few places, coarse sandy (loose sands and weakly loamy sands) deposits occur. In accordance with markings on analyzed maps, the soils derived from these sandy parent materials belongs to rusty soils (PSC 2011) and Brunic Arenosols (IUSS Working Group WRB, 2015).

Some toeslope and footslope positions within Trzeciewnica and Dębowa Góra test plots are covered by soils designated by $\mathrm{D}$ letter on soil-agricultural maps. These pedons contain both: thick mollic horizons and gleyic properties. According to Polish Soil Classification (2011) they represent type of black earths which correspond to Gleyic Phaeozems and Gleyic Chernozems (Kabała et al. 2016). Only individual contours have been marked with the symbol Dd emphasizing occurrence of colluvial material on the surface of mentioned soils. South parts of test plots Trzeciewnica, Dębowa Góra, Ślesin and Las Minikowski encompasses the ice-marginal stream valley floor filled by organic soils (WRB - Histosols) developed from biogenic deposits - peats and muds.

Maps of potential erosion indicate the high possibility of strong and widespread erosional alteration of soil cover within all studied test plots (Fig. 3). The main reason for this is large inclination of slopes regardless the different susceptibility to water erosion of various groups of soils.

\section{DISCUSSION}

Taking into consideration the results obtained from the potential erosion map, whole classes of soil truncation should be represented within soil cover of studied areas. In particular, it concerns the clayilluvial soils located on slopes of the valley. Successive stages of truncation differ significantly from each other in respect of basic properties of these soils sequence of genetic horizons, colour, texture, depth to upper boundary of argic horizon etc. (Kobierski 2013, Podlasiński 2013, Świtoniak 2014). It was probably easily noticeable at the stage of field work during the creating of soil-agricultural maps which should be reflected in the designations of particular contours. An overview of these delineations confirms significant diversity of clay-illuvial soils in the analyzed test plots. The comparison of descriptions recorded in the form of cartographic symbols with properties of pedons divided into several classes of vertical texturecontrast soil truncation (Świtoniak 2014) enabled to
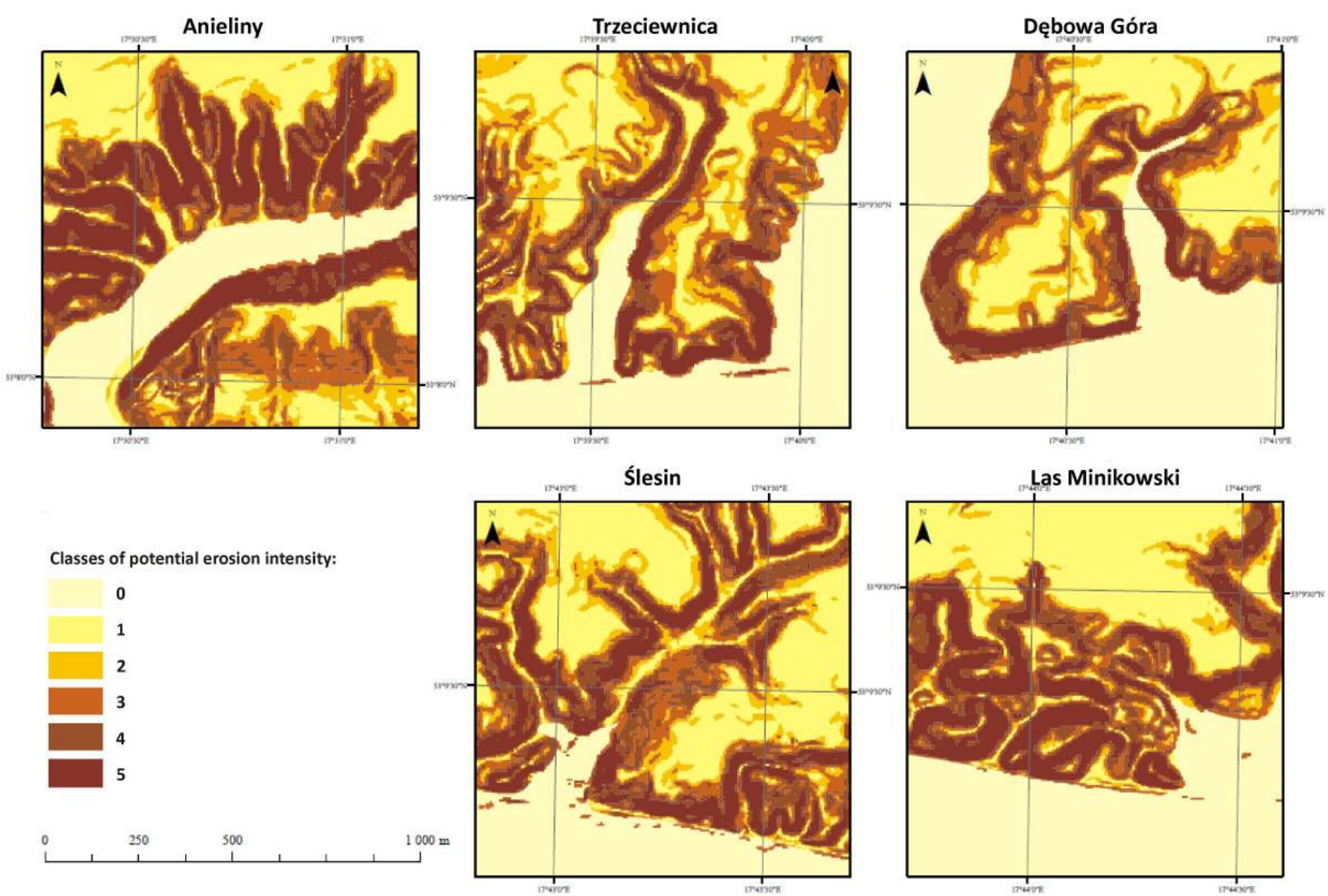

FIGURE 3. Maps of potential erosion. Classes of the intensity of surface water erosion according to Wawer and Nowocień (2007): 0 - no erosion, 1 - weak erosion, 2 - moderate erosion, 3 - average erosion, 4 - strong erosion, 5 - very strong erosion 
find the correlation between these two categories (Fig.

4). The following classes were distinguished:

0 . The organic soils and black earths located on flat bottom of the valley were classified as noneroded. These soils occur in places not exposed to destructive activity of slope processes. Due to lack of data and assuming the protective, antierosion role of forests, this category includes also the soils covered by forests (Ls PGL).

1. Soils marked with symbols Bw and with change in texture from sandy to loamy material at depth 50-100 cm (e.g. Bw pgm:gś, Bw pgl:gl) have been assigned to a pedons minimally shallowed by erosion. The argic horizon occurs at depth comparable with depth to $\mathrm{Bt}$ in natural reference forest pedons (Świtoniak 2014). Apart from Bt horizon, these soils are characterized by presence of cambic Bw horizon in the upper part of the eluvial zone. It is manifested by B signature on soil-agricultural maps. This letter was used for contours with soils containing subsurface brown in color horizon what is typical for brown clay-illuvial soils (WRB - Neocambic Luvisols). In view of these data, described pedons represent fully developed soils with whole sequence of genetic horizons: A-Bw-E-2Bt2C(k) (Kühn 2003; Świtoniak 2014). Furthermore, contours designated as rusty soils (e.g. 6Bw

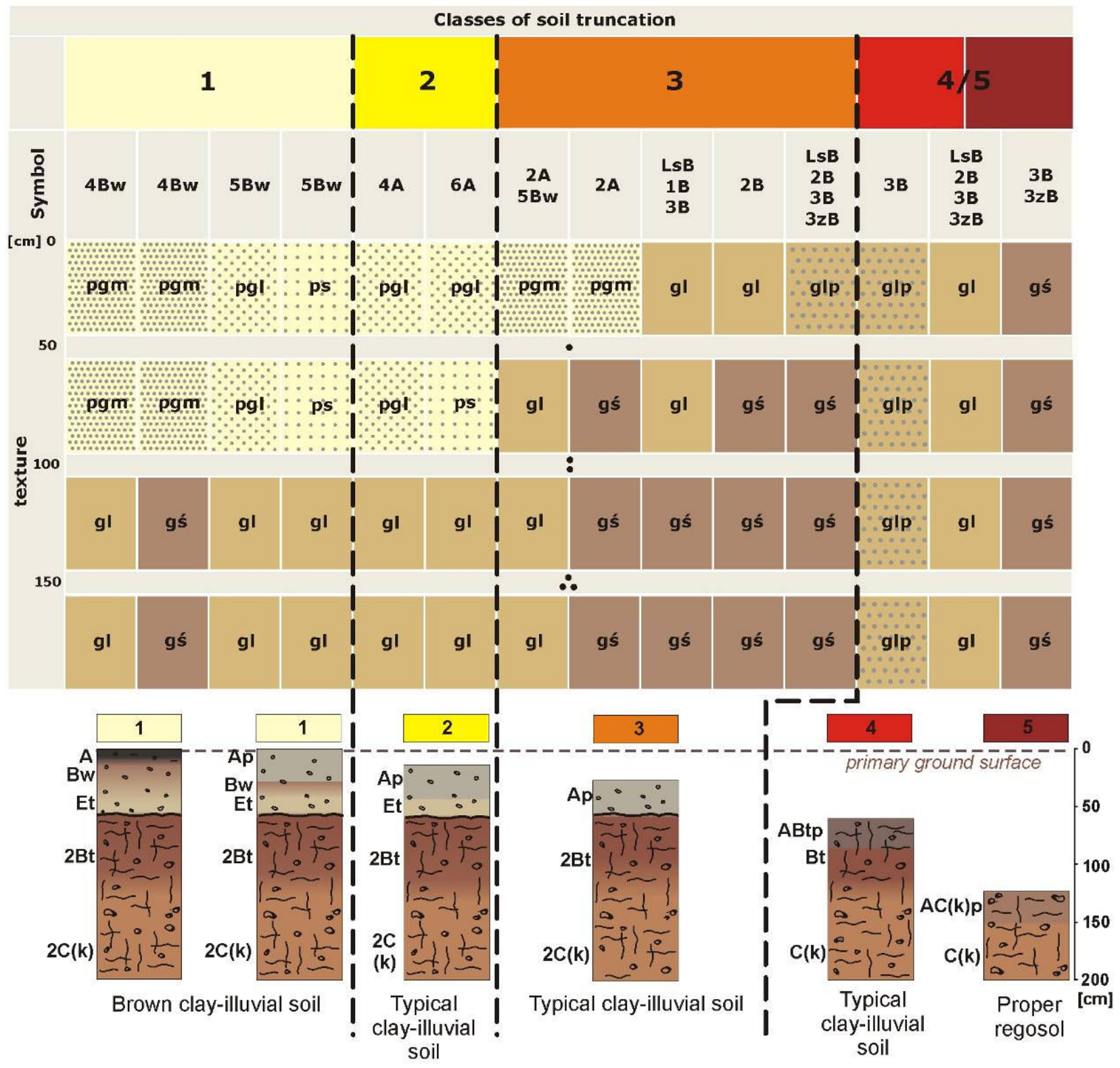

FIGURE 4. The comparison of cartographical designation on soil-agricultural maps with classes of soil truncation ( 1 - fully developed profiles, 2 - slightly eroded, 3 - moderately eroded, 4 - strongly eroded, 5 - completely eroded) 
ps.pl; 7Bw pl), have been classified to this category. Occurrences of sideric horizons indicate low erosional alterations of these sandy pedons (Świtoniak and Bednarek 2014).

2. Slightly eroded clay-illuvial soils are characterized by bleached and light in colour eluvial horizons $\mathrm{E}$ between the surface horizons Ap and argic horizons (Świtoniak 2014). Soils with such sequence of genetic horizons were designated on analysed maps by using letter A. The thickness of the eluvial zone $(\mathrm{Ap}+\mathrm{E}$ horizons) is still greater than plow layer and exceed $50 \mathrm{~cm}$ (Fig. 4). Moreover, these soils are characterized by a clear contrast in texture on the $\mathrm{E} / \mathrm{Bt}$ boundary.

3. In moderately eroded soils further reduction of solum lead to disappearance of $E$ horizons. The surface Ap horizons overlay directly Bt horizons. If surface horizons contain only bleached material from primarily E horizons, the colour and texture (strongly loamy sand on loam) contrast between Ap and Bt is clear. In such instances letter A was used to mark these soils on maps (e.g. A pgm.gl). Except that, the illuvial material from Bt could be partly incorporated into Ap by plowing in the past. This reduced the vertical diversity of properties as texture (sandy loam on loam) or colour on which could be expressed by using B letter on the maps (e.g. B gl.gś). Notwithstanding this, the surface horizons still contain at least partially material from primarily eluvial zone as reflected by their more coarse (compared with $\mathrm{Bt}$ ) texture. In most cases the abrupt textural change takes place at depth not exceeding $50 \mathrm{~cm}$.

4/5) Strongly eroded soils are vertically homogenous in texture (Fig. 4). The textural class of loam dominates in whole profiles. The eluvial horizons were entirely removed by erosion. Surface horizons include only illuvial material from argic horizons (ApBt). At this stage of truncation, clay-illuvial soils have morphology identical to brown earths (WRB - Cambisols). The A-B-C soil horizon sequence explains why they always were marked on the maps by letter B: B glp, B gl, B gś (Świtoniak et al. 2016). Nevertheless, recent research has shown that they should be classified as strongly eroded clay-illuvial soils. A preliminary field work (Pietrzak 2014) demonstrated that described countours contain also pedons represent $\mathrm{ACp}-\mathrm{C}$ or $\mathrm{ACkp}-\mathrm{Ck}$ morphology with no other genetic horizon than an ochric, plowed surface horizon. This minimal development allows to classify these soils only as completely eroded Regosols. Total truncation of primarily pedons is evidenced by presence of significant quantity of calcium carbonates in the some surface horizons (Świtoniak 2014). The combination of these two stages of erosion in one soil-unit on the maps is caused by their considerable morphological resemblance. It concerns in particular the Regosols developed from non-calcareous glacial tills (Świtoniak et al. 2013).

The application of developed interpretative principles allows calculating the share of soil truncation classes areas (Fig. 5). The comparison of the obtained results with share of potential erosion intensity grades reveals significant relationship between these two components (classes of truncation and potential erosion intensity) within Trzeciewnica, Dębowa Góra and Ślesin. In the plots Anieliny and Las Minikowski areas of soil truncation can not be compared with potential erosion due to significant areas of forests and insufficient cartographical data.

The strongly and completely eroded pedons cover $11,2 \%$ of whole investigated areas. This value differs substantially (between 2,8\% and 16,9\%) on the each test plot. In case of Dębowa Góra it appears to be greatly undervalued, especially when compared to the share of very strong potential erosion grade. This is also confirmed by the studies on erosion in other young morainic regions e.g. Wełtyńska plain (Podlasiński 2003) or Brodnica Lake District (Świtoniak and Bednarek 2014) where soils truncated to the parent material or with remains of Bt horizon under Ap cover $18 \%$ and $11 \%$, respectively. Presumably, some parts of the contours marked as moderately eroded soils on existing maps belong to the strongly eroded pedons.

Considering only the deforested plots (2-4), acreages of moderately stage of truncation correspond to the sum of areas which are moderately, average and strongly exposed to potential erosion. Their share amounts from 35,2 to $46 \%$ of soil cover. These high values considerably exceeds results obtained for hummocky morainic plateaus (Podlasiński 2013, Świtoniak and Bednarek 2014) because are associated with specific morphometry of steep and very long slopes of ice-marginal stream valley.

Significant slope inclination is also reflected in the low spatial share of fully developed and slightly eroded soils. They occur within almost flat and weakly exposed to erosion areas of morainic plateau in north parts of test plots. Despite such a large amount of eroded pedons only single contours of colluvial soils developed from slope deposits accumulated within aggradation zone were marked. The underestimation of their range on soil-agricultural maps was already 

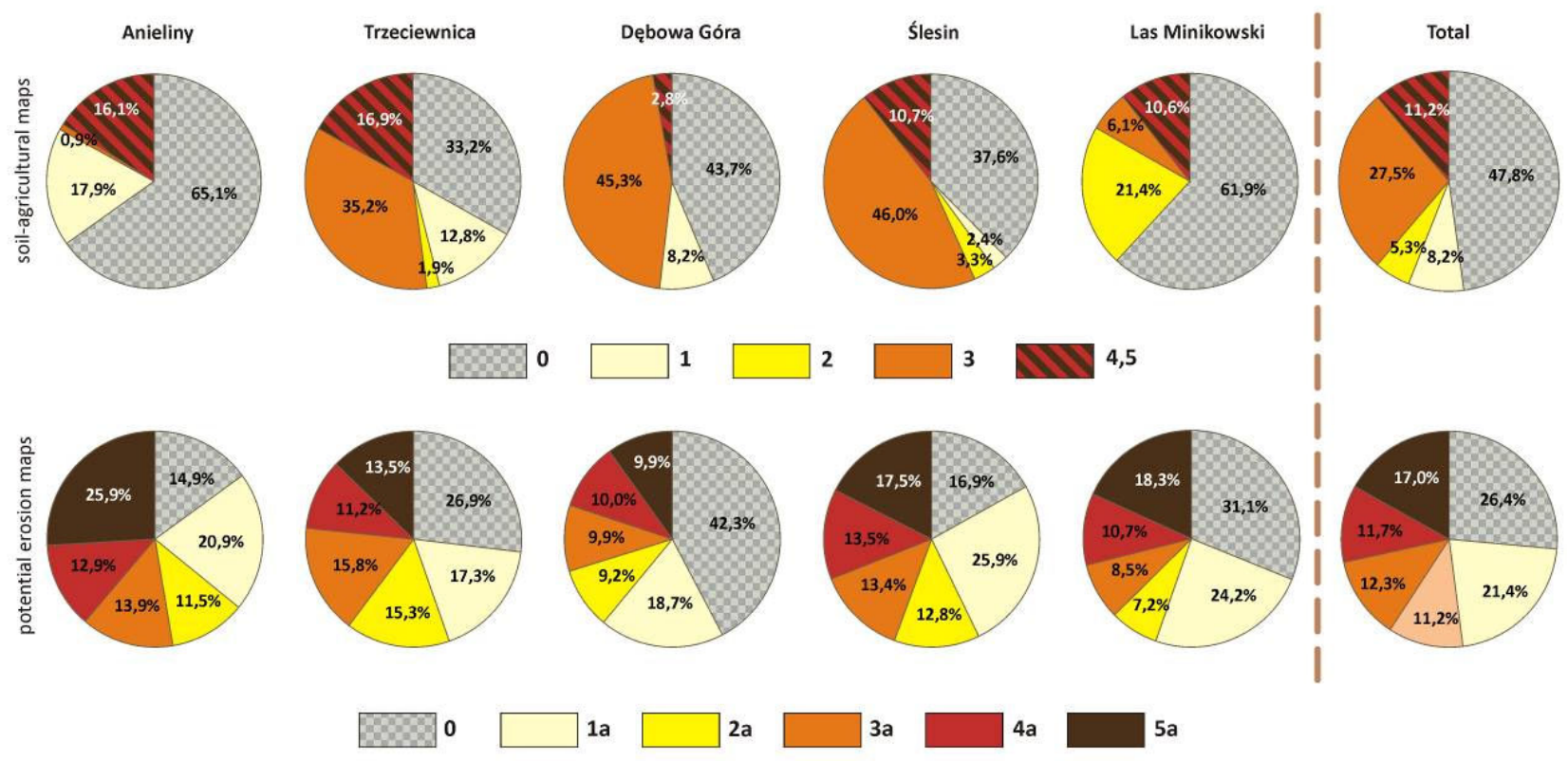

FIGURE 5. Share of soil truncation classes areas calculated on the basis of soil agricultural maps compared with share of grades of potential erosion intensity. 0 - not eroded and forested soils; 1 - fully developed profiles; 2 - slightly eroded; 3 - moderately eroded; 4, 5 - strongly and completely eroded (Świtoniak 2014); 1a - weak erosion, $2 \mathrm{a}$ - moderate erosion, $3 \mathrm{a}$ - average erosion, $4 \mathrm{a}$ - strong erosion, $5 \mathrm{a}$ - very strong erosion (Wawer and Nowocień 2007)

stressed for example by Bieniek (1997) and Świtoniak (2015). The presence of large acreages of soils developed from thick colluvial deposits on lower part of studied slopes was proved by Pietrzak (2014).

\section{CONCLUSIONS}

The proposed interpretation of soil-agricultural maps reveals their significant value in studies on extent and degree of erosional alterations recorded in soil cover. Designations on the maps contain a large amount of useful information about soil erosion:

1. On the basis of cartographic symbols relating to the texture and type of pedons it is possible to separate a several classes of truncation: (i) fully developed profiles; (ii) slightly eroded, (iii) moderately eroded, (iv) strongly or completely eroded clay-illuvial soils.

2. The vast majority of soils interpreted so far in literature as brown earths (Cambisols) proved to be clay-illuvial soils (mostly Luvisols) in different stages of truncation.

3. Moderately, strongly and completely eroded soils cover more than $50 \%$ of unforested areas within investigated slopes.

4. Almost complete lack of colluvial soils on maps is result of underestimation of the role of the accumulation processes in aggradation zone.

5. Actual degree and extend of erosional transformation refer to results obtained from potential erosion maps. However, as a result of the protective effects of grass vegetation, contemporary processes of erosion have low intensity. It leads to conclusion that truncated soils are remnants of the intensive slope processes and agricultural use of the area in the past.

Future studies on application of soil-agricultural maps as a valuable source in erosional research require validation of elaborated interpretation. Detailed field work should be carried out to confirm described correlations between particular soil cartographic contours and classes of truncation. An important element of further research is also finding indications based on existing cartographic resources for determining extend of colluvial soils.

\section{REFERENCES}

Bednarek R., Pokojska U., Dziadowiec H., Prusinkiewicz Z., 2005. Badania ekologiczno-gleboznawcze. Wydawnictwo Naukowe PWN, Warszawa: $344 \mathrm{~s}$.

Bieniek B., 1997. Properties and development of deluvial soils in Mazurian Lakeland. Acta Academiae Agriculturae Technicae Olstenensis. Agricultura, 64 suppl. B, Olsztyn: 80 pp. (in Polish with English abstract).

Cieśla W., 1968. Genesis and properties of arable soils developed from glacial tills of the Kujava Plateau. Rocz. WSR Poznań, Prace habilitacyjne 18, Poznań: 60 pp. (in Polish with English summary).

Cieśla W., Wojtasik M., Miraszewski R., Rogalski D., 1978. Soils of the Chełmno Upland developed from silty deposits. Roczniki Gleboznawcze - Soil Science Annual 29(1): 127-140 (in Polish with English summary). 
Dobers E.S., Ahl C., Stuczyński T., 2010. Comparison of Polish and German maps of agricultural soil quality using GIS. Journal of Plant Nutrition and Soil Science 173: 185-197.

Drzewiecki W., Mularz S., 2005. Model USPED as a tool for assessment of soil erosion and deposition effect. Roczniki Geomatyki 3(2): 45-55 (in Polish with English abstract).

Drzewiecki W., Wężyk P., Pierzchalski M., Szafrańska B., 2014. Quantitative and qualitative assessment of soil erosion risk in Małopolska (Poland), supported by an object-based analysis of high-resolution satellite images. Pure and Applied Geophysics 171(6): 867-895.

Galon R., 1958. Wydmy śródlądowe Polski: vol. 2. PWN, Warszawa: 7-59.

IUSS Working Group WRB, 2015. World Reference Base for soil resources 2014. International soil classification system for naming soils and creating legends for soil maps. Update 2015. World Soil Resources Report No. 106. FAO, Rome.

Józefaciuk A., Józefaciuk C., 1992. The structure of water erosion hazard in physiographic regions of Poland. Pamiętniki Puławskie (Polish Journal of Agronomy) 101: 23-49 (in Polish).

Kabała C., Świtoniak M., Charzyński P., 2016. Correlation between the Polish Soil Classification (2011) and international soil classification system World Reference Base for Soil Resources (2015). Soil Science Annual 67(2): 88-100.

Kaszubkiewicz J., Tasz W., Kawałko D., Serafin R., 2011. USLE model simplification proposal for application in a small agricultural catchment area. Roczniki Gleboznawcze - Soil Science Annual 62(1): 7-81.

Klimowicz Z., Uziak S., 2001. The influence of long-term cultivation on soil properties and patterns in an undulating terrain in Poland. Catena 43: 177-189.

Kobierski M., 2013. Morphology, properties and mineralogical composition of eroded Luvisols in selected morainic areas of the Kujavian and Pomeranian Province. University of Technology and Life Sciences, Bydgoszcz (in Polish with English summary).

Kühn P., 2003. Micromorphology and Late Glacial/Holocene genesis of Luvisols in Mecklenburg-Vorpommern (NEGermany). Catena 54: 537-555.

Latocha A., 2012. Small catchments as sediment archives of past human activities, the example of Sudetes Mountains (SW Poland). Zeitschrift für Geomorphologie 56: 115-130.

Marcinek J., Komisarek J., 2004. Anthropogenic transformations of soils of Poznań Lakeland as a results of intensive agricultural farming. AR. Poznań (in Polish with English summary).

Maruszczak H., 1991. Chemical denudation. [In:] Geography of Poland. The natural environment. PWN, Warszawa (in Polish).

Olson K.R., Phillips S.R., Kitur B.K., 1994. Identification of eroded phases of an Alfisol. Soil Science 157(2): 108-115.

Orzechowski M., 2008. The properties of eroded and deluvial soils in the Mazurian Lakeland and the Sępopolska Plain. Roczniki Gleboznawcze-Soil Science Annual 59(3/4): 236-242.

Paluszek J., 2010. The changes of soil cover as a result of erosion. Prace i Studia Geograficzne 45: 279-294 (in Polish with English summary).

Paluszek J., 2013. Assessment of soil structure of Luvisols developed from loess classified in various complexes of agricultural suitability. Soil Science Annual 64(2): 41-48.

Pietrzak D., 2014. Morfologia i właściwości gleb nisz wód zmarzlinowych w Pradolinie Noteci - Warty. MA thesis manuscript.
Department of Soil Science and Landscape Management, NCU, Toruń, Unpublished.

Podlasiński M., 2013. Denudation of anthropogenic impact on the diversity of soil cover and its spatial structure in the agricultural landscape of moraine. West Pomeranian University of Technology, Szczecin (in Polish with English summary).

Polish Soil Classification (Systematyka Gleb Polski), 2011. Roczniki Gleboznawcze - Soil Science Annual 62(3): 1-193 (in Polish with English summary).

Przewoźna B., 2014. Changes of bulk density, air-water properties and morphology of soils in basins without outlets as an effect of erosion and anthropogenic denudation (a study from northwestern Poland). Soil Science and Plant Nutrition 60: 30-37.

Ratajczak-Szczerba M., Paluszkiewicz R., 2015. Analiza sedymentologiczna osadów denudacyjnych w niszy niwalnej w krawędzi Pradoliny Toruńsko-Eberswaldzkiej (Sedimentological analysis of denudation deposits in nivation niche in the edge of the Torun-Eberswalde ice-marginal valley). Landform Analysis 28: 73-85 (in Polish with English abstract).

Rejman J., Rodzik J., 2006. Poland. [In:] Soil Erosion in Europe. (Boardman J., Poesen J., Editors). John Wiley \& Sons: 95106.

Sobiech M., 2012. Geneza rzeźby glacjalnej I i dynamika ostatniego lądolodu w rejonie Górzna, manuscript of master thesis, Torun.

Sinkiewicz M., 1998. The development of anthropogenic denudation in central part of northern Poland. UMK, Torun (in Polish with English summary).

Strzemski M., 1985. Application of soil-agricultural maps in division of agricultural lands into fields. Roczniki Gleboznawcze - Soil Science Annual 36(1): 113-118 (in Polish with English abstract).

Szrejder B., 1998. Some properties and taxonomic position of soils evolved as a result of anthropogenic denudation in Koniczynka on the Chełmno moraine plateau. Zeszyty Problemowe Postępów Nauk Rolniczych 460: 499-511 (in Polish with English abstract).

Święchowicz J., 2012. Water erosion on agricultural foothill slopes (Carpathian Foothills, Poland). Zeitschrift für Geomorphologie 56(3): 21-35 (Supplementary, Issues).

Świtoniak M., 2014. Use of soil profile truncation to estimate influence of accelerated erosion on soil cover transformation in young morainic landscapes, North-Eastern Poland. Catena 116: $173-184$.

Świtoniak M., 2015. Issues relating to classification of colluvial soils in young morainic areas (Chełmno and Brodnica Lake District, northern Poland). Soil Science Annual 66(2): 57-66.

Świtoniak M., Bednarek R., 2014. Anthropogenic denudation. [In:] Anthropogenic transformations of soil cover of Brodnica Landscape Park. (Świtoniak M., Jankowski M., Bednarek R., Editors). Wydawnictwo Naukowe UMK, Toruń: 57-84 (in Polish).

Świtoniak M., Markiewicz M., Bednarek R., Paluszewski B., 2013. Application of aerial photographs for the assessment of anthropogenic denudation impact on soil cover of the Brodnica Landscape Park plateau areas. Ecological Questions 17: 101-111.

Świtoniak M., Mroczek P., Bednarek R., 2016. Luvisols or Cambisols? Micromorphological study of soil truncation in 
young morainic landscapes - Case study: Brodnica and Chełmno Lake Districts (North Poland). Catena 137: 583-595.

Uggla H., Mirowski Z., Grabarczyk S., Nożyński A., Rytelewski J., Solarski H., 1968. The water erosion process in hilly areas of north-eastern part of Poland. Roczniki Gleboznawcze Soil Science Annual 18(2): 415-446 (in Polish with English summary).
Wawer R., Nowocień E., 2007. Digital map of water erosion risk in Poland: a qualitative, vector-based approach. Polish Journal of Environmental Studies 16(5): 763-772.

Weckwerth P., 2010. Evolution of the Torun Basin in the Late Weichselian. Landform Analysis 14: 57-84.

Received: June 22, 2016

Accepted: February 16, 2017

Associated editor: A. Lachacz

\section{Przydatność map glebowo-rolniczych w określaniu klas ogłowienia gleb}

Streszczenie: Erozja gleb jest czynnikiem prowadzącym powszechnie do silnych przekształceń pokrywy glebowej obszarów młodoglacjalnych Polski północnej. Efektem procesów stokowych są zarówno gleby zerodowane (ogłowione) występujące na wierzchowinach pagórków oraz w górnych partiach stoków, jak i gleby powstałe w miejscach akumulacji materiału deluwialnego. Wiedza i dane dotyczące zasięgu przestrzennego lub intensywności procesów erozyjnych pochodzi głównie z geoprzestrzennych modeli i czasochłonnych prac terenowych. W celu zmniejszenia czaso- i pracochłonności badań związanych z erozją niezbędne jest zatem stosowanie istniejących już materiałów kartograficznych. Głównym celem przedstawionych badań jest opracowanie klucza reinterpretacyjnego umożliwiającego oszacowanie stopnia zerodowania gleb (głównie płowych) na podstawie informacji zawartych na mapach glebowo-rolniczych. Cel ten osiagnięto przez porównanie informacji zawartych na mapach ze szczegółowym opisem poszczególnych klas ogłowienia gleb i danymi pochodzącymi z map erozji potencjalnej. Zastosowanie uzyskanego klucza reinterpretacyjnego pozwoliło na obliczenie zasięgu przestrzennego poszczególnych klas ogłowienia gleb na wybranych powierzchniach testowych. Pięć takich powierzchni (każda o wielkości $1 \mathrm{~km}^{2}$ ) zostało zlokalizowanych na zboczach wysoczyznowych Środkowej Doliny Noteci i Kotliny Toruńskiej. Zaproponowane wytyczne do interpretacji map glebowo-rolniczych wskazują na dużą przydatność tego źródła kartograficznego w badaniach erozji gleb.

Słowa kluczowe: pokrywa glebowa, erozja gleb, gleby płowe, krajobraz młodoglacjalny, Polska północna 